\title{
International Law Analysis of The Restrictions Imposed on Remote Sensing Satellite Through Shutter Control
}

\author{
Dyan Franciska Dumaris Sitanggang
}

International Law, Faculty of Law, Universitas Katolik Parahyangan

Ciumbuleuit 94, Bandung, West Java 40141

\begin{abstract}
This paper addresses the issue concerning state's control over the activities of remote sensing (RS) satellites that can surveil its territory, as well as other states territories, and also able to disseminate confidential information, which could jeopardize the state's national security and foreign policy. The author proposes that Indonesia should assert its right to control the activities of RS satellites as other countries do through 'shutter control'regulations. The author also examines several approaches that could be used to determine the allowed RS satellite activities, as well as other countries practices that might help to formulate new norms concerning space-based activities.
\end{abstract}

Keywords: satellite application, remote sensing, shutter control.

\section{Intisari}

Tulisan ini membahas isu kendali negara atas aktivitas satelit penginderaan jarak jauh, berdasarkan masalah kemampuan satelit penginderaan jarak jauh untuk pengamatan atas wilayah nasional negara asalnya juga negara-negara lain, menyebarkan informasi yang bersifat rahasia yang berbahaya bagi keamanan nasional dan kebijakan internasional negara tersebut. Penulis menyarankan agar Indonesia menyuarakan hak mengendalikan aktivitas satelit penginderaan jarak jauh sebagaimana dilakukan negara-negara melalui regulasi 'kendali bidik'. Tulisan ini pun menganalisa pendekatan yang bisa digunakan untuk menentukan aktivitas satelit penginderaan jarak jauh yang diperbolehkan dan praktek negara-negara dapat membantu pembentukan norma baru dalam aktivitas luar angkasa.

Kata Kunci: satelit, penginderaan jarak jauh, kendali bidik.

\section{Pokok Muatan}

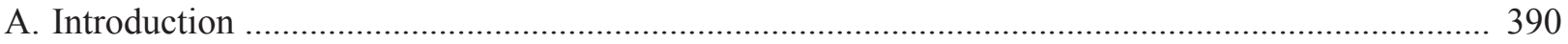

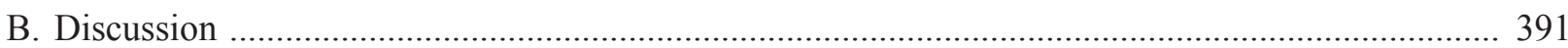

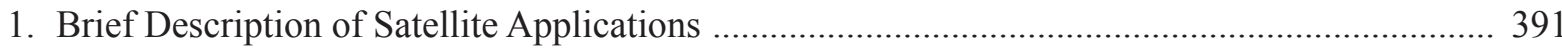

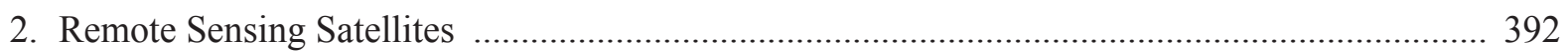

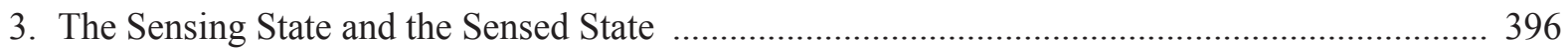

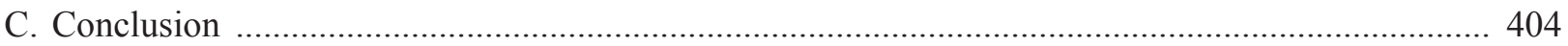




\section{A. Introduction}

"A state's territory is its castle. No one is allowed to enter it without its permission ... the world resembles a series of immense airtight petroleum storage tanks representing the various national States with their threedimensional sovereignty ... the arrival of the space age was as if the lid on the tank was suddenly ripped off. And, if we can change the image, it was like opening up an anthill with all the ants inside scurrying round wondering how to cover themselves and their secrets and stores."

It is in human nature to advance, explore and understand. It is shown in all aspect of our life, including activities reaching out beyond Earth. Key technological advance has come from satellites such as television broadcast, communication, navigation, weather forecast, and even satellite observations to safeguard the environment and assist in disaster management. It shows that satellites provide everimportant services to humankind.

States are responsible for all space activities, including satellite operations; hence, the rights and obligations of outer space activities are states' direct concern. Most of the principles within space law were made from the collaboration of states, primarily through the United Nations. Thus, states act both as the creator and the subject of the said rules. It also encompasses operations by private entities. Moreover, states would be held responsible and liable on the international level for cases concerning space activities, either acting as host state or launching state, each with their own share of responsibilities, as every space activity is considered as national activity.

Furthermore, to enforce their responsibility over private entities, states must enact national space legislation, particularly the licensing systems of satellites, to exercise legal control over the operation. ${ }^{2}$ However, outer space constitutes as territorium extra commercium where there is no territorial sovereignty and jurisdiction held by states. Nevertheless, states have quasi-territorial jurisdiction only over space objects and their registry, including all things and persons on board.

The characteristics of outer space explained above make the activities conducted there constitutes as an international activity. It is not only because outer space is free for exploration and use by all states, which makes it not a subject to national appropriation, but also because the operation of satellites does not only concern the launching state(s). Satellite operations also impact the other states, as it could collect data in space over areas dictated by the satellite's orbit - such as in remote sensing operations - which may be conducted in the third states' territory. It is inevitable that third states fear the threat to its national security, given the possibility of data collection on their territory from space and potential dissemination of those data.

As the current international legal framework regarding remote sensing is inadequate, it is worth mentioning that several states have enacted national legislation to deal with the activities of its own remote sensing satellites within and outside their territory, as well as its data dissemination. Thus, it can also foster cooperation between states. Unfortunately, Indonesia does not yet have a clear legal position. The formulation of national regulations should be considered by Indonesia to strengthen the current laws, and also to contribute to the making of customary international law concerning restriction on remote sensing satellites.

The author analyzes remote sensing activity in general, freedom to conduct remote sensing, and its limitation in the form of shutter control, for states that rely on its own remote sensing satellite or using remote sensing satellite services provided by another country based on the principles of international law and space law. Furthermore, the author discusses national legislation on remote

Bin Cheng, 2004, Studies in International Space Law, Clarendon Press, Oxford, pp. 573, 577-578, as quoted by Gbenga Oduntan, 2012, Sovereignty and Jurisdiction in the Airspace and Outer Space: Legal Criteria for Spatial Delimitation, Routledge, New York, p. 269.

Frans von der Dunk, "United Nations Principles on Remote Sensing and the User" in Ray Harris (ed.), 2002, Earth Observation Data Policy and Europe, Swets \& Zeitlinger B.V., Netherlands, p. 31. 
sensing satellite enacted by other states to understand the uniformity of the practices in governing remote sensing activities, and what can Indonesia do to stay secure and stay open to beneficial technological advancement in this particular space-based activity, simultaneously.

\section{B. Discussion}

\section{Brief Description of Satellite Applications}

Satellite applications include at least satellite communications, satellite broadcasting, satellite navigation and positioning, geostationary meteorological satellites, remote sensing and Earth observation, and space-based information systems. ${ }^{3}$ Over the past half-century, thousands of satellites have been launched to space. Communication satellites, space navigation and positioning satellites, meteorological satellites, and remote sensing satellites have a tremendous practical contribution to human activities. Combination of commercial services and governmental and defense (military-related) operation of satellites represents an ever-growing global industry.

A communication satellite is a satellite that use radio frequencies to convey and receive information from one point to the other, and vice versa. International Telecommunication Union (ITU) was established to deal with matters concerning the shared global use of radio spectrum and satellite orbits. ITU allocates radio frequency by making different categories of satellite services and provides it for the use of different radio frequency bands for these services. Although ITU deals with telecommunication, all forms of satellite activities, including defense-related application, remote sensing, space navigation, meteorological satellites, and time synchronization, need to operate active communications links to convey information to the Earth and receive commands from Earth locations. ${ }^{4}$

Most of the communication satellites are located in orbits called geosynchronous (GEO) and geostationary $(\mathrm{GSO})^{5}-$ a unique orbit above the equator where the orbital velocity happens to constitute the exact speed needed to complete a revolution around the world exactly every 23 hours and 56 minutes and 4 seconds. Meteorological satellites are also stationed on those orbits. Satellites in this orbit revolves around the world once every day. Thus, its earth station does not have to change the antenna to follow the satellite, unlike other orbits. Satellites in GEO and GSO will also have wide coverage of the earth surface. ${ }^{6} \mathrm{GSO}$ trajectory is above equatorial states: Colombia, Congo, Ecuador, Kenya, Uganda, Zaire, Brazil, and Indonesia. Among those states, Indonesia has the longest GSO, approximately $13 \%$ of the total length. ${ }^{7}$

Space navigation and positioning satellites that fall under the Global Navigation Satellite Systems (GNSS) category could provide highly precise positioning and timing information using radio messages. There are four major GNSS systems, namely the American NAVSTAR GPS, the Russian GLONASS, the European Galileo, and the Chinese Beidou (Compass). Technically, the system composed of three main segments: the space, the ground, and the user segment. Each space segment consists of a constellation of 24 to 30 satellites orbiting the Earth at approximately 19.000 to $24.000 \mathrm{~km}$. Each satellite emits a signal to the Earth containing the position and time of the satellite. The distance from the satellite to the receiver is measured as accurately as possible by an atomic clock. ${ }^{8}$ The services provided are integral to

Joseph N. Pelton, et al., "Satellite Applications Handbook: The Complete Guide to Satellite Communications, Remote Sensing, Navigation, and Meteorology" in Joseph N. Pelton, et al. (eds.), 2013, Handbook of Satellite Applications, Springer, New York, p. 5.

Ibid., p. 71.

GEO is an orbit synchronized with the Earth's rotation (it may or may not be above the Earth's equator, as long as the satellite's rotational period is one day), while GSO is a GEO orbit located just above the Earth's equatorial plane and appears stationary at a point in the sky when seen from Earth.

Juajir Sumardi, 1996, Hukum Ruang Angkasa (Suatu Pengantar), PT Pradnya Paramita, Jakarta, p. 104.

Ibid., p. 105.

Lesley Jane Smith, "Legal Aspects of Satellite Navigation” in Frans von der Dunk and Fabio Tronchetti (eds.), 2015, Handbook of Space Law, Edward Elgar Publishing, Massachusetts, p. 556. 
many aspects of common security, economic and social infrastructure, including national and global security, economic growth, transportation safety, and scientific research.

Furthermore, meteorological satellites also play a crucial role, not only for reliable weather forecasts but also for key storm warnings, potential disaster alerts, and climate change observation. Meteorological services using satellites were pioneered by the United States (US) and by the National Aeronautics and Space Administration (NASA) experimental satellites, followed by Europe, Russia, Japan, China, and India. ${ }^{9}$ Moreover, to obtain higher resolution images, polar-orbiting meteorological satellites and meteorological GSO satellites are combined to provide broad patterns of weather formation. The satellites observe the weather using the electromagnetic spectrum. Unlike other satellite services, meteorological satellites remain entirely as government services and most meteorological satellite imaging data is widely shared. ${ }^{10}$ Some polar and GSO meteorological satellites are powered by remote sensing capability to monitor and predict severe weather and climate trends indicated by sea surface temperatures, biomass burning, and cloud cover in the longer term. ${ }^{11}$

A brief description of other uses of satellites besides for remote sensing is purposely made to demonstrate the indispensable role of satellites and show that different satellites are connected to each other. Such connectivity forms a combination of services and cooperation, involving more than one state, and accordingly, could affects another states' interest as well. Therefore, remote sensing is not the only satellite activity that concerns more than one states, albeit with more legal and security issues to deal with.

\section{Remote Sensing Satellites}

\section{a. Remote Sensing Satellites'Activities}

Remote sensing has evolved since ages ago, from the use of mapping and cartography in ancient Mesopotamia and Egypt, balloons in American civil war, cameras attached to pigeons, photo-taking solid rocket created by Alfred Nobel, large box kites by the US Army Signal Corps, airplane used for aerial reconnaissance, all the way to satellites used nowadays. ${ }^{12}$ It was during the First and Second World War that reconnaissance from the sky was hugely developed to supply military needs, and the use of satellite for remote sensing also begun since then. In 1958, the Soviets launched Zenit spy satellites, and the US authorized Corona system, which was the highest resolution imaging satellite available back then. ${ }^{13}$

Remote sensing is basically a means to acquire information about distant objects without directly being in contact with them. Remote sensing may show its manifestation in two ways: photographic remote sensing and space-based or satellite remote sensing. Aerial remote sensing is a form of observation through cameras mounted on balloons and aeroplanes. Moreover, under the Chicago Convention 1944, pilotless aircraft cannot fly over the territory of a state without special authorization, in a form of consent from the state where the aircraft flown. ${ }^{14}$ On the other hand, as outer space does not fall under any state's territorial jurisdiction, the sensing states do not need the consent of the states below before launching the remote sensing satellites.

The difference between these two

\footnotetext{
Joseph N. Pelton, et al., "Introduction to Space Systems for Meteorology" in Handbook of Satellite Applications, Op.cit., p. 958.

Ibid., p. 959

W. Paul Menzel, "Remote Sensing Applications with Meteorological Satellites", NOAA Satellite and Information Service, University of Wisconsin, Madison, pp. 17-18, available at $<$ https://cimss.ssec.wisc.edu/rss/benevento/source/AppMetSat06.pdf>.

Scott Madry, "Introduction and History of Space Remote Sensing" in Handbook of Satellite Applications, Op.cit., p. 658-660.

Ibid., p. 660-661.

Article 8 Convention on Civil Aviation, opened for signature 7 December 1944, 15 UNTS 295 (entered into force 4 April 1947).
} 
types of remote sensing also lies in how it captures image. Unlike cameras with films, satellite remote sensing utilizes electronic photosensitive sensors to take digital images ${ }^{15}$ and uses the electromagnetic waves emitted, reflected, or diffracted by the sensed objects. ${ }^{16}$ Satellite remote sensing is also able to do repeated-observation over a certain area easier and with less restriction, ${ }^{17}$ and is not limited by physical national boundaries. ${ }^{18}$ Back then, remote sensing was utilized primarily for reconnaissance and other military-related purposes. Due to technological advancements and the increased number of space actors, it is now used for civil and commercial purposes. Earth observation is deemed a requirement for the research on global ecological change. ${ }^{19}$ The first satellite remote sensing system for civil purpose was the Television and Infrared Observation Satellites (US TIROS). Sensing from space has helped in various fields such as meteorology, disaster management, environment, and delimitation of international boundaries. ${ }^{20}$ Data acquired is given a digital value and sent to a ground station by a radio communications link to be processed into usable information, and the process is technologically advanced.

Satellite remote sensing is enhanced with the use of other scientific ways to utilize the data obtained, such as the use of Geographic Information Systems (GIS) that allows integration of remote sensing data with population and other demographic data, in situ environmental telemetry, global positioning system, and other demographic data. ${ }^{21}$ Remote sensing satellites are continuously developing, enabling them to produce high-resolution images. A prominent example of satellite remote sensing is the availability of Google Earth.

Sensing may be passive or active. Passive sensing collects electromagnetic or other radiation emanating from the target whether that is reflecting radiation (e.g. sunlight) or originates in the target itself (e.g. heat); whereas, active sensing requires the device to electromagnetically illuminate the sensed target, making the reflection of illumination captured by its sensors. ${ }^{22}$ Photographic (aerial) remote sensing is an example of passive sensing, while radar is an example of active sensing. Sensing satellites usually orbit either in the GSO or low earth orbit (LEO). ${ }^{23}$ As most remote sensing satellite is passive and used for earth observation, it uses Sun-synchronous polar orbit, mostly between 500 and 800 kilometers above the Earth (LEO) to provide high and moderate resolution coverage of the planet, allowing the satellite to pass over the same location on the Earth periodically at the same time of day with the same solar illumination. ${ }^{24}$ The lighting provided by the Sun is needed for the satellite to produce a

\footnotetext{
Fabio Tronchetti, "Legal Aspects of Satellite Remote Sensing” in Handbook of Satellite Applications, Op.cit, p. 502.

6 Principles Relating to Remote Sensing of the Earth from Outer Space, UN GA Res. 41/65, 3 December 1986, UN Doc. A/AC.105/572/Rev.1, at 43 .

20 See GISGeography, "100 Earth Shattering Remote Sensing Applications and Uses", http://gisgeography.com/100-earth-remote-sensingapplications-uses/, acessed 2 January 2018.

Tronchetti, Op.cit., p. 503. LEO is an orbit between 200-5.500 kilometers above Earth. One of the differences between LEO and GEO is that the satellite orbital period is around 90 minutes, while in GEO is 24 hours (see also I. H. Ph. Diederiks-Verschoor, et al., 2008, An Introduction to Space Law, Kluwer Law International BV, The Netherlands, p. 20-21).

24 Madry in Handbook of Satellite Applications, Op.cit., p. 663.
} 
visible infra-red image of the sensed objects. Also, by orbiting in the area near the Earth's surface, sensing satellites will be able to capture detailed information of the observed areas and object, and it is also protected from solar radiation. There are several military satellites operating in the dark but mostly for communication, because to obtain the image, the sensed object must emit, reflect or diffract electromagnetic waves, and it can be done using the solar energy.

\section{b. Legal Aspects of Remote Sensing Activities}

Satellite remote sensing activities are governed under international law, specifically, space law. It is firstly regulated in the Treaty on Principles Governing the Activities of States in the Exploration and Use of Outer Space, including the Moon and Other Celestial Bodies (Outer Space Treaty), which entered into force $1967 .{ }^{25}$ The treaty is recognized as the Magna Carta of space law. It also codified most of the basic legal principles concerning the use of outer space, which will be further elaborated in other specific agreements or international conventions.

The key aspects of Outer Space Treaty are the notion that sovereignty of states does not extend to outer space, space-based activities are governed by international law, non-appropriation, freedom for all states to use outer space and celestial bodies for peaceful purpose, the responsibility of states that could result in international liability for damage caused to other states, respect for the rights and interests of other states, and the principle of equality. ${ }^{26}$ Despite the concern for the national security issue, remote sensing itself is not prohibited. As there is no state can own outer space, all states able to use the outer space to conduct remote sensing activity, either using its own satellites or through cooperation with other states, as long as it is conducted for peaceful purposes. The Outer Space Treaty encompasses fundamental principles of space governance and has gained near-universal acceptance and adherence. ${ }^{27}$

Moreover, there is no international convention governing remote sensing, but instead regulated under the Principles Relating to Remote Sensing of the Earth from Outer Space (Remote Sensing Principles) made by the United Nations General Assembly (GA) in $1986 .^{28}$ The Remote Sensing Principles set out the conditions and responsibilities expected from the sensing states. Although it is a GA resolution, there are different views for the binding force of this document. Interests of the sensed states set forth in the Remote Sensing Principles are as follows:

“... Such activities shall not be conducted in a manner detrimental to the legitimate rights and interests of the sensed State." - Principle IV

25 Treaty on Principles Governing the Activities of States in the Exploration and Use of Outer Space, Including the Moon and Other Celestial Bodies, General Assembly Resolution 2222 (XXI), 19 December 1966, UN Doc. A/RES/2222(XXI).

26 Ibid., Art. I: "[...] shall be free for exploration and use by all States without discrimination of any kind, on a basis of equality and in accordance with international law, and there shall be free access to all areas of celestial bodies. [...]"

Art. II: "[...] is not subject to national appropriation by claim of sovereignty, by means of use or occupation, or by any other means."

Art. IV: "[...] shall be used [...] exclusively for peaceful purposes. [...]"

Art. VI: "State Parties to the Treaty shall bear international responsibility for national activities in outer space, including the Moon and other celestial bodies, $[\ldots]$ carried on by governmental agencies or by non-governmental entities, and for assuring that national activities are carried out in conformity with the provisions set forth in the present Treaty. [...]"

Art. VII: "Each State Party to the Treaty that launches or procures the launching of an object into outer space, including the Moon and other celestial bodies, and each State Party from whose territory or facility an object is launched, is internationally liable for damage to another State Party to the Treaty or its natural or juridical persons by such object or its component parts on the Earth, in air space or in outer space, including the Moon and other celestial bodies."

27 G. S. Sachdeva, "Select Tenets of Space Law as Jus Cogen", in R. V. Rao, et al., 2017, Recent Developments in Space Law, Springer Nature, Singapore.

28 Principles Relating to Remote Sensing of the Earth from Outer Space, UN GA Res. 41/65, 3 December 1986, UN Doc. A/AC.105/572/Rev.1, at 43 . 
"As soon as the primary data and the processed data concerning the territory under its jurisdiction are produced, the sensed State shall have access to them on a non-discriminatory basis and on reasonable cost terms. The sensed State shall also have access to the available analyzed information concerning the territory under its jurisdiction in the possession of any State ..." - Principle XII

“... consultations with a State whose territory is sensed in order to make available opportunities for participation and enhance the mutual benefits to be derived therefrom." - Principle XIII

On the value of GA resolution, the International Court of Justice (ICJ) stated:

"The cumulative impact of many resolutions when similar in content voted for by overwhelming majorities and frequently repeated over a period of time may give rise to a general opinio juris and thus constitute a norm of customary international law." ${ }^{29}$

In 2004, during the Berlin Conference, it was discussed that most of the Principles envisaged within Remote Sensing Principles are considered to reflect a customary international law that is binding on states, ${ }^{30}$ such as principle of non-restrictions based on geography, no prior consent of the sensed state is required or freedom to do observation from the space, principle of equality, and no limitation imposed on the sensing capabilities. It is because of practical universality apparent through the states' behavior during the resolution-making process, and the adherence to the principles while conducting the activities. Moreover, the principles have grown from the basic foundation laid down in the Outer Space Treaty.

However, the same cannot be said on other matters such as data dissemination, ${ }^{31}$ access to remote sensing data, ${ }^{32}$ and other technical aspects, including the activities of private entities. It is partly because the provisions concerning the sensing states' obligations toward the sensed states are said to have rather ambiguous wording and loopholes, and most of the provisions in the Remote Sensing Principles end up benefitting only developed nations, as none of the proposals regarding the rights of the sensed states and obligations of the sensing states was incorporated in the final version of Remote Sensing Principles as the sensed or developing states originally proposed. ${ }^{33}$ Additionally, as remote sensing has been changed since then, states are creating their own national law to keep up with their rights and obligations as the sensing state or the sensed state.

On the bright side, even though there are only several of the provisions can be categorized as customary international law, regulations enacted by states to govern their own remote sensing activities, which have substantial similarities, may become a customary international law if they fulfil the element of state practice and opinio juris, and further serve as the basis of formulating another international convention. It should be considered that the time and numbers of states participating are not necessarily the

Western Sahara, Advisory Opinion, 1975 ICJ Reports 12.

International Law Association, "Report on the Legal Aspects of the Privatization and Commercialization of Space Activities", Space Law Committee, Berlin Conference, 2004, p. 4; Carl Q. Christol, 1991, Space Law: Past, Present, and Future, Kluwer Law and Taxation, Boston, pp. 90-94; Youssef Sneiffer, “The Implication of National Security Safeguards on the Commercialization of Remote Sensing Imagery”, Seattle University Law Review, Vol. 19, 1996, pp. 548, 552.

31 S. M. Williams, "Reflections and Suggestions on Remote Sensing and International Law", German Journal of Air and Space Law, vol. 50, 2001, p. 417.

32 Aniel Caro De Beer, 2015, The Refusal of Access to High Resolution Remote Sensing Data for Reasons of National Security: A (New) Rule of Customary International Law?, Thesis, University of Pretoria, pp. 19-20.

33 Ito, Op.cit., pp. 53-54. 
requirement for a custom to be acknowledged as law. For instance, in the North Sea case, ICJ stated that at times, a customary international law could be formed in a rapid manner. ${ }^{34}$ But above all, it must be practiced by the states "whose interests are especially affected". 35 Space-based activity is a rapidly developing technology, and unfortunately, not all states are actively exercising their right for space exploration and exploitation. However, state practice can also be seen through its nonobjection to the emerging customs, behavior in an international forum such as the United Nations GA while discussing particular space issues or resolution voting, adoption of customs into its national law, and international relation with other states concerning spacebased activities, particularly remote sensing. Indonesia was one of the equatorial states claiming the sovereignty over the GSO in which some sensing satellites are orbiting. However, it did not last long, and Indonesia has established cooperation with other states such as Australia to enhance Indonesia's remote sensing capability, ${ }^{36}$ and China for, among others, maritime surveillance and environmental monitoring. ${ }^{37}$ Most of the provisions enshrined in Indonesia's laws on space-based activities are the manifestation of either the Outer Space Treaty or principles adopted in GA resolutions.

\section{The Sensing State and the Sensed State}

\section{a. Freedom of Exploration versus 'Shutter Control'}

Outer space is a vast area beyond Earth without any owner and is a subject to common freedom of exploitation. However, such freedom must be exercised in conformity with international law, considering the interest of other states, especially the developing ones. The author argues that there are two forms of limitation on the said freedom. The first is in the form of international responsibility, which regulated in Article VI, VII, and VIII of the Outer Space Treaty, respectively:

"States Parties to the Treaty shall bear international responsibility for national activities in outer space, including the Moon and other celestial bodies, whether such activities are carried on by governmental agencies or by nongovernmental entities ... The activities of non-governmental entities in outer space ... shall require authorization and continuing supervision by the appropriate State Party to the Treaty ...".

"Each State Party to the Treaty that launches or procures the launching of an object into outer space, including the Moon and other celestial bodies, and each State Party from whose territory or facility an object is launched, is internationally liable for damage to another State Party to the Treaty or to its natural or juridical persons by such object or its component parts ...".

"A State Party to the Treaty on whose registry an object ... shall retain jurisdiction and control over such object, and over any personnel thereof, while in outer space or on a celestial body ...".

The Outer Space Treaty provides the frameworks concerning jurisdiction, control, and ownership. It is only natural that the registration to be done in the state which exercises control over the operation of the launched object. Due to the scale and complexity of the space activity, states may initiate cooperation. On the other hand, since dual registration is not allowed, cooperating

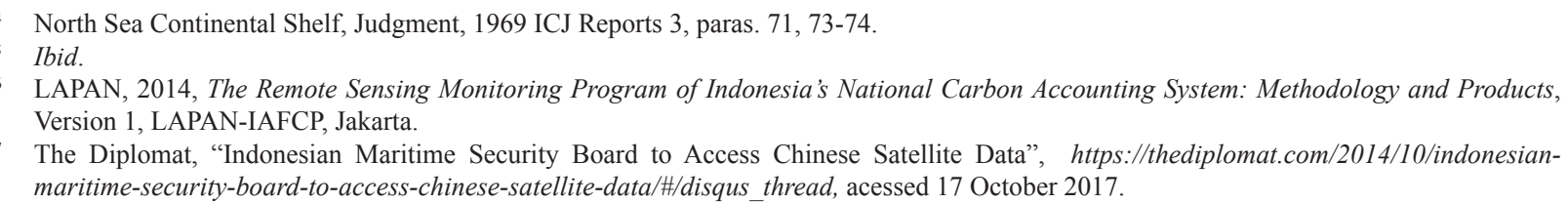


states must decide between them which state will they designate as the registration state. Responsibility will be allocated to each accordingly, following the formula within the Liability Convention. ${ }^{38}$ The state who procures the launching or state from whose territory or facility the launching took place, may also be held liable should the space objects cause damage to other states. Thus, the registration serves only as prima facie evidence for state jurisdiction, ${ }^{39}$ and case-bycase assessment is needed.

Not only that states are internationally responsible over its space activities, states are also not entirely free in conducting any of it. It means that they ought to pay due heed to the interest of other states, particularly their national security. Therefore, states' national security constitutes as the second limitation of the freedom of exploitation. Article XI of the Outer Space Treaty states that:

"In order to promote international cooperation ... Signatories are obliged to inform the United Nations Secretary-General, as well as the public, and the international scientific community to the greatest extent feasible and practicable, of the nature, conduct, locations, and results of space activities."

However, such obligation is not clearly explained, inter alia, to what extent is 'greatest extent feasible and practicable' required by the said article, how about the intellectual property rights of the inventor, et cetera.

Remote Sensing Principles provides a few provisions concerning the interest of the sensed state. However, due to its position as a non-binding resolution by the GA, it is rather difficult for the sensed states to defend their interests. For instance, although the sensed states are supposedly entitled to the privileges of accessing primary and processed data on a non-discriminatory basis and reasonable cost,${ }^{40}$ that is not necessarily the case ${ }^{41}$ First, there is no legal mechanism to force the sensing states to release the data, and thus, when a sensing state does allow the sensed state to access the data, it does so on the basis of good faith; and second, 'on reasonable cost' may depend on the market price at the moment. ${ }^{42}$ Therefore, it depends on both sensing and sensed states to protect their own national security and foreign relation by building up a protective mechanism through their domestic legislation, using Remote Sensing Principles as the foundation. However, going back to the core principles of space law concerning non-appropriation and freedom of exploitation, there is only one way available and currently practiced by several states as their safeguard measure, which is an image-taking restriction placed on the satellite and data operators for national security or foreign policy reasons by the state of registration.

There are some instances where states impose total denial of access over a particular territory, but due to the commercialization of remote sensing and the availability of the Internet, this has proven ineffective. ${ }^{43}$ Furthermore, denial of access might disadvantage the state itself. Despite the national security concern, remote sensing is mainly used to observe meteorological events and disasters, and has proven helpful in

Convention on International Liability for Damage Caused by Space Objects, opened for signature 29 November 1971, 961 UNTS 187 (entered into force 1 September 1972).

39 Imre A. Csabafi, 1971, The Concept of State Jurisdiction in International Space Law: A Study in the Progressive Development of Space Law in the United Nations, Martinus Nijhoff, The Hague, p. 109.

40 Principles Relating to Remote Sensing of the Earth from Outer Space, UN GA Res. 41/65, 3 December 1986, UN Doc. A/AC.105/572/Rev.1, Principle XII.

Dunk, Op.cit., pp. 36-37.

Tronchetti, Op.cit., p. 523

Lyall, Op.cit., pp. 427-428. 
predicting natural occurrences. On the other hand, considering that space must be used for the benefit of humankind - a principle echoed by the Outer Space Treaty, the sensing state may be held liable for not transmitting relevant information they possess that in the end causing preventable harm or damage to the sensed state.

\section{b. 'Shutter Control': Dealing with the Dual-Use of Technology}

Currently, only some of the developed states have their own remote sensing satellites system, e.g. the US, Canada, France, Russia, and China. Governments from other states are cooperating with those states. Indonesia, for instance, made an agreement with China (see above) and bought high-resolution satellite images from SPOT (Satellite pour l'Observation de la Terre) owned by France. ${ }^{44}$ Moreover, Japan is collaborating with NASA for ASTER (Advanced Spaceborne Thermal Emission and Reflection Radiometer), where Japan owns ASTER as one of the remote sensory devices on board the Terra satellite launched by NASA in 1999. The result of the said collaboration was the release of the most complete topographic map of Earth. ${ }^{45}$

The limitation imposed by states upon particular areas of their national territory is called localized degrading of satellite imagery, ${ }^{46}$ or commonly known as 'shutter control' regulation. States may deem some sites in their territories for security reasons as in need to be protected, for example, military bases or facilities, because they might be subject to attack. The limitation may appear in the form of national regulation or actions taken by states. Moreover, whether the states possess remote sensing satellite system, they usually have their own national law governing remote sensing activities, ${ }^{47}$ as it is important to safeguard the national security by denying or restricting access to information, and to guarantee the priority access of the government to the system's capabilities in times of crisis. ${ }^{48}$

The US laws and policies relate to with remote sensing reflect the government's effort to stay as the leading force in the field while safeguarding its national security and foreign policy interests. The operation that was initially public started to be transferred to the private sector. The Land Remote Sensing Policy Act is the principal legislation governing the US remote sensing activities, ${ }^{49}$ whereas, the implementations are regulated in some policies and regulations, for example, the Presidential Decision Directive 23 (PDD-23). ${ }^{50}$ PDD-23 encapsulated a measure to protect the US' national security and international relations, justifying the interruption of operation known as 'shutter control':

"Whennational security or international obligations and/or foreign policy may be compromised as defined by the Secretary of Defense or the Secretary of State, respectively, the Secretary of Commerce may after consultation with the appropriate agencies, require the licensee to limit data collection and or distribution by the system to the extent necessitated by the given situation." ${ }^{51}$

44 Ari Supriyanti Rikin, "Lapan Serahkan Data Penginderaan Jauh Resolusi Tinggi pada 11 Instansi”, http://www.beritasatu.com/iptek/244745lapan-serahkan-data-penginderaan-jauh-resolusi-tinggi-pada-11-instansi.html, acessed 27 January 2017.

45 National Aeronautics and Space Administration, "NASA, Japan Release Most Complete Topographic Map of Earth", https://www.nasa.gov/ topics/earth/features/aster-20090629.html, acessed 27 January 2017.

46 Lyall, Loc.cit.

47 For example, The United States: The 1992 Land Remote Sensing Policy Act; Canada: Act governing the Operation of Remote Sensing Space Systems 2005; France: French Space Operations Act; German: German Act on Satellite Data Security.

48 Tronchetti, Op.cit., p. 526.

49 The Land Remote Sensing Commercialization Act, Public Law 98-365, 98th Congress, HR 5155, 17 July 1984.

50 Ito, Op.cit., p. 78.

51 Presidential Decision Directive 23, United States Policy on Foreign Access to Remote Sensing Capability, 9 March 1994. 
Shutter control is a form of control or oversight through which a state limits or disables the ability of its firms to provide imagery at high-resolution (in comparison with images from other commercial sources), or to hamper the distribution of data acquired from foreign satellites within its territory if it harms the state's national security or international relation. According to the mentioned provision, the US the shutter control rule applies to any US public or private remote sensing operators. If a satellite captures a high-resolution image of a protected area (of the state itself or of other state but in risk of jeopardizing its foreign policy) that is far better in terms of quality and spatial resolution than what is already available, this rule prohibits the firm to sell or disseminate the said product in the US. Moreover, the procurement of sensitive data is restricted to the US Government or recipients approved by the US Government. The earlier version of Land Remote Sensing Policy Act was amended with the KylBingaman Amendment to the 1997 National Defense Authorization Act, which prohibits the US satellites to provide details on the border of Israel/Syria more than those from foreign commercial sources. ${ }^{52}$

Canada also has a comprehensive national law governing remote sensing, which is the Remote Sensing Space Systems Act, ${ }^{53}$ whereas the Remote Sensing Space Systems Regulations provide the detailed rules of the primary act. ${ }^{54}$ The Act regulates the activities of remote sensing actors through licensing and supervision using measures of enforcement such as inspections and sanctions for actors under its jurisdiction and control, ${ }^{55}$ and applies both to commercial and other governmental satellites. It regulates the obligations of the licensee and rights of the government to manage the operation of remote sensing system and control the distribution of data obtained. The Canadian government has the right to interrupt remote sensing services if they believe it would harm Canada's national interest, ${ }^{56}$ by delaying distribution and reduction of spatial resolution. ${ }^{57}$

As for Germany, although they do not have a launch site in its territory, due to the development of high-resolution remote sensing satellites and involvement of private sector, ${ }^{58}$ the Parliament enacted German Act on Satellite Data Security. ${ }^{59}$ It establishes the governmental control over collection and dissemination of data acquired from high-performance remote sensing satellites to minimize the threat to Germany's national security and the security of other nations. ${ }^{60}$ The Act applies to German satellites, satellites operated from Germany, or satellites operated by German nationals or legal persons. A remote sensing operator needs an approval, while data operator needs a license. ${ }^{61}$ Without approval or license, the product will not be able to be disseminated.

Kyl-Bingaman Amendment to the 1997 National Defense Authorization Act, 15 USC 5621. See also Lyall, Loc.cit. See also Ito, Op.cit., p. 81; See also Raphael Prober, "Shutter Control: Confronting Tomorrow's Technology with Yesterday's Regulations", Journal of Law and Politics, Vol. 19, 2003, pp. 203-252.

53 Remote Sensing Space Systems Act, SC 2005, c. 45.

54 Remote Sensing Space Systems Regulations, SOR/2007-66.

Ito, Op.cit., p. 82.

Presidential Decision Directive 23, United States Policy on Foreign Access to Remote Sensing Capability, 9 March 1994 Section 14.

Thomas Gillon, "Regulating Remote Sensing Space Systems in Canada - New Legislation for a New Era", Journal of Space Law, Vol. 34, 2008, p. 30.

58 Commercialization of remote sensing data makes it possible for states with remote sensing satellite system or provider to sell the captured images to other states. A state may also cooperate with other states to launch a satellite.

59 Satellite Data Security Act Federal Gazette BGBI.2007 I. No.58, 28 November 2007.

60 Ito, Op.cit., p. 86.

61 Satellite Data Security Act, Section 1(1). 
Before a data distributor complies with a data request, it must undergo a 'sensitivity check' to analyze the content, the location observed, the person that purchased the data, the country of destination, and the time between data acquisition and the processing of the data request. ${ }^{62}$ If it is deemed to be non-sensitive, the data may be distributed without further approval. Otherwise, the distributor must obtain a permit from the Federal Office. ${ }^{63}$ The German government also has the right to priority access to data in emergency situations. The providers are obliged to prioritize the Government to access the data if there is a threat to the German military and civilian forces in a foreign country or to foreign officers employed at German foreign embassies. However, it is restricted to rare occasions of crisis. ${ }^{64}$

Meanwhile, in France, remote sensing is addressed in the French Space Operations Act, specifically under the Title VII concerning Space-based Data, as France does not have any specific Act on remote sensing. The provisions in Space Operation Act are supported by a decree titled French Decree on Remote Sensing containing the applications of measures under Title VII. Due to the significant impact of data collection and dissemination, the part of French legislation governing data control was developed separately by the Ministry of Defense, and the rest of it by the Council of State. ${ }^{65}$ Furthermore, under the Title VII, Article 25, it is possible for the Government to impose restrictions on remote sensing actors to safeguard the state's national interest. Administrative Authority, which is the Secretary-General for National Defense (SDGN) is bestowed with the task to make sure that the primary operator of space-based remote sensing data does not interfere with the fundamental interests of the state. ${ }^{66}$ For example, France suspended data dissemination to Iraq during the Gulf War. The restrictions may come in the form of immediate suspension on data distribution for a limited time, delay in distribution, and permanent prohibition of data dissemination for certain locations. ${ }^{67}$ For instance, the location of French troops abroad, nuclear plants in France, or the location of allied troops abroad. ${ }^{68}$ Regarding data exploitation and distribution, it can only be done if the remote sensing actors (individual and juridical person) have made a declaration to the SDGN. Operation without a declaration, and those who do not comply with data restriction regulation, would be imposed with a civil penalty. ${ }^{69}$

Furthermore, China has a de facto shutter control regulation, ${ }^{70}$ that it will not provide its $4 \mathrm{~m}$ resolution data of Chinese territory from its own Beijing-1 satellite to users outside China. ${ }^{71}$ Not only restricting the data dissemination, China also has the policy to place a restriction on a map scale for dissemination. The National Mapping Service of China has up-to-date maps available, and unauthorized users are allowed

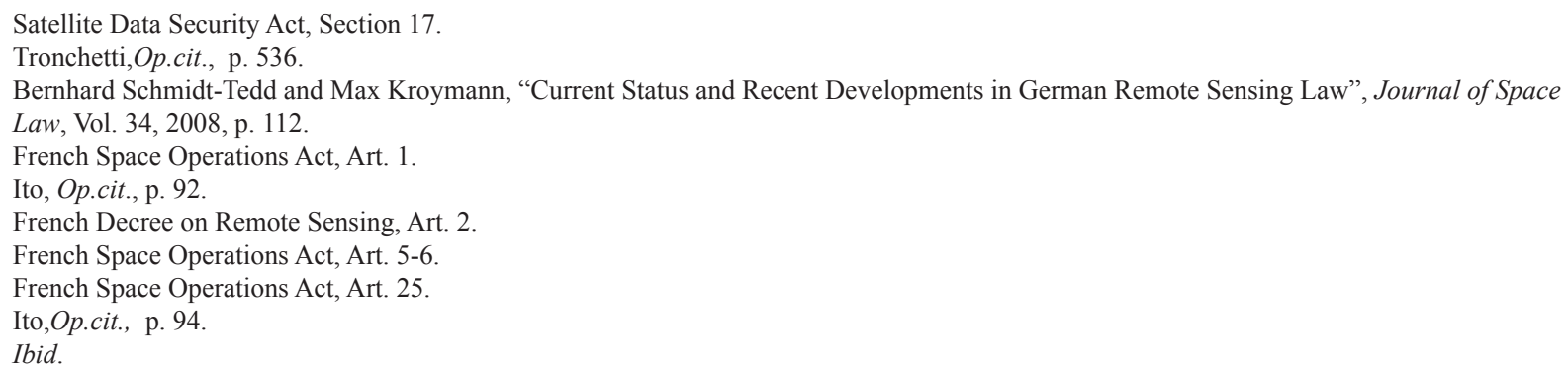


by the China Government to access only up to $1: 1$ million scale maps. ${ }^{72}$

India has its own Remote Sensing Data Policy with two purposes, to establish a licensing mechanism and guidelines to control remote sensing data dissemination. ${ }^{73}$ License and/or permission should be given by the Department of Space that assigns the licensing operation to two entities, the former is the National Remote Sensing Centre (NRSC) handling acquisition/distribution of data within India both from Indian and foreign satellites, and the latter is Antrix Corporation for acquisition/distribution of data outside of India, ${ }^{74}$ while data dissemination is subject to the three-tier policy that divides how data can be disseminated according to the resolution. Data between $5.8 \mathrm{~m}$ and $1 \mathrm{~m}$ subject to screening, to ensure that sensitive areas are excluded. ${ }^{75}$ Government users do not require further clearance to distribute data higher than 1m; while other users should be reviewed by High-Resolution Image Clearance Committee. ${ }^{76}$ The definition of 'sensitive areas' is not provided in the Remote Sensing Data Policy. However, the example of it can be seen in the agreement concluded by the Indian government with the Space Imaging, that IKONOS (Google Earth) will degrade sensitive areas such as military bases and airfield before distributed in India. ${ }^{77}$ NRSC also forbids the dissemination of data containing India's borders up to eighty kilometers inside the territory, including the states of Jammu and Kashmir. ${ }^{78}$
Those aforementioned national laws are examples of domestic regulation governing remote sensing. Russia and Japan also have their domestic regulations as well. Meanwhile, Indonesia does not have any specific law governing remote sensing. It is only regulated under Indonesia Space Act, ${ }^{79}$ specifically in Article 15 to Article 22. It covered data collection, data processing, data archive and distribution, data utilization, and information dissemination. Ground stations can only be operated by LAPAN (National Institute of Aeronautics and Space of Indonesia). Collection and distribution of high-resolution data for the government are conducted solely by LAPAN. Indonesia is receiving low, medium, and high-resolution data from foreign operators such as LANDSAT-7, LANDSAT-8, Terra/Aqua, NOAA-18/19, SPOT-6 and SPOT-7. To receive the data in almost real-time, direct receiving is done by ground stations in ParePare, Rumpin, and Pekayon. ${ }^{80}$ Under Article 23 , specific measures about remote sensing activities shall be regulated under separated Government Regulation. However, it is still yet to be finished. ${ }^{81}$ Data utilization and dissemination guideline are to be provided by LAPAN, and in 2015 LAPAN has published a utilization guideline for data received from LANDSAT-8.

Moreover, Indonesia does not have any specific provision in the Indonesia Space Act concerning shutter control. The only protection for national security is that only LAPAN can distribute high-resolution data

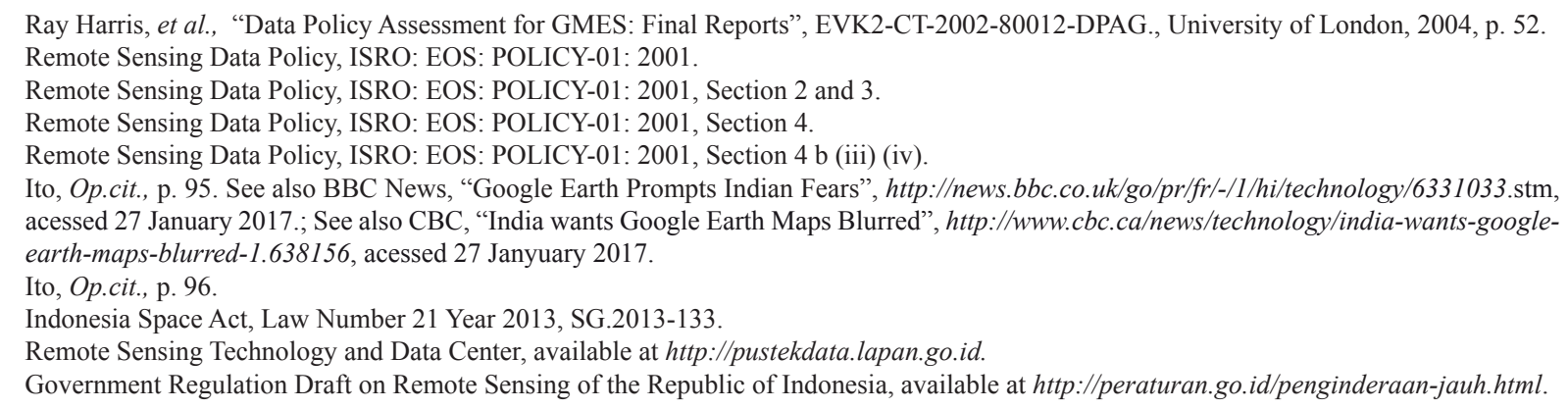


for governmental institutions, whereas low and medium resolution data can be distributed by LAPAN and other remote sensing operators. It can be categorized as shutter control, yet it is deemed inadequate as there is no provision that gives the Government the right to interrupt services and the right of priority access in the event of an emergency.

It may be categorized as shutter control, but still deemed inadequate as there is no provision concerning the Government's rights to interrupt services and priority access in the event of an emergency, or when the national security is threatened. Furthermore, there is also no provision concerning the penalty should be given when the data dissemination is jeopardizing Indonesia's national security and/or foreign policy. Also, there is no clause that empowers the Government (ministries or through its agencies) to do security or sensitivity check upon the data before being distributed in Indonesia. Even the term of licensing is not elaborated enough.

Considering the vastness of the Indonesian archipelago and how Indonesia is now keeping up with the technological advancement of remote sensing by cooperating with foreign remote sensing systems, it is imperative that Indonesia should have a specific regulation to guarantee the government control of remote sensing activities and data distribution, especially in the era of dual-use of technology. ${ }^{82}$ Sensitive information can be used by 'malicious person', such as terrorists, for terrorism operation. Indonesia may also limit the dissemination of data if it is concerned with certain places, such as the location of military bases, the way other states protect theirs. With a vast territory, it is a lot easier to exercise control through effective regulation concerning remote sensing activities and distribution of satellite imagery, either by governmental institutions, private entities, or public-private remote sensing operators.

\section{c. Formulation of Customary Inter- national Law}

Article 38(1) of the Statute of the ICJ defined international 'custom' as evidence of a general practice accepted as law. ${ }^{83}$ To determine whether a practice can be deemed as law, the practice should be complemented with the conviction of the states that they are legally obliged to do so, and violation may give rise to legal consequences. It is called the two-element theory for an international practice to be a law: widespread and consistent states practice, and the element of opinio juris ${ }^{84}$ National laws can be categorized as state practice if it is one of the official Acts of the government. To be deemed as 'general', particular practice does not have to be done in a long time, but it should be done by the states whose interests are especially affected, in a widespread and consistent fashion. ${ }^{85}$ Custom can be crystallized into a treaty provision, as treaty provision may become customary for states not parties to the treaty. As for GA resolutions, ICJ stated that for a resolution to be customary international law, it depends on "its content and conditions of its adoption." $" 86$

Shutter control is beneficial to protect the state's national security and foreign policy. The activity itself is not ipso facto prohibited; instead, it is tackled in the dissemination phase. State that does not

82 Herbert Lin, "Governance of Information Technology and Cyber Weapons" in Elisa D. Harris (ed.), 2016, Governance of Dual-Use Technologies: Theory and Practice, American Academy of Arts \& Sciences, Cambridge, p. 112.

83 Statute of the International Court of Justice, 18 April 1946, 33 UNTS 993.

84 Continental Shelf (Libyan Arab Jamahiriya/Malta), Judgment, 1985 ICJ Reports 29, para. 27. See also The Diplomat, "Indonesian Maritime Security Board to Access Chinese Satellite Data", https://thediplomat.com/2014/10/indonesian-maritime-security-board-to-access-chinesesatellite-data/\#/disqus_thread, acessed 17 October 2017.

maritime-security-board-to-access-chinese-satellite-data/\#/disqus_thread, acessed 17 October 2017, paras. 71-72.

86 Nuclear Weapons, Advisory Opinion, 1996 ICJ Reports 226, paras. 254-255. 
rely on foreign remote sensing satellite but its own protects its interest by not allowing the operator to sell the acquired data, either domestically or abroad. Furthermore, state that relies on data provided by foreign satellite may assign agencies to do sensitivity or security check before distributing or selling the data to public or private entities in need. On the other hand, the sensing states can initiate cooperation with the sensed states to determine the excluded areas, as the sensed state has the right to obtain the primary and processed data. Without approval from the licensing state, sensitive data will not be able to be sold anywhere, and incompliance may result in losing the license, distribution delay, reduction of spatial resolution, or other forms of civil penalties. However, the licensing or sensing state should enforce the law in a thorough assessment, so the rights of remote sensing operators are not jeopardized.

Observing that states are creating their own national remote sensing laws to regulate non-governmental and public-private remote sensing operations, and also an increasing number of restrictions to access and distribution of remote sensing data, it is possible for 'shutter control' to become customary international law. The practices reveal that there is a significant number of restrictions to the access and distribution of data, particularly high-resolution data. ${ }^{87}$ Shutter control is not a violation of international law, as states do not forbid the use of outer space above its territory, but instead protect its own territory by protective measures.

Indonesia, albeit not specific enough, has a regulation that bestows the power to disseminate high-resolution images only to LAPAN, it means that states foresee a form of shutter control in some way. Therefore, as shutter control might be categorized as customary international law, states could exercise it to protect their national security in the absence of international provisions concerning shutter control, even though some states might not have similar provision exist within its domestic legislation system. In other words, if Indonesia deems that a particular territory needs to be protected, Indonesia can assert its rights to limit remote sensing activity. Indonesia should enact a law (or amend the existing law) that empowers government agency (or LAPAN itself), to do sensitivity check, adopts operational indicators for national security and foreign policy, governs the remote sensing data's buyand-sell mechanism within Indonesia, and firmly establishes areas that fall under special protection - with strong and legally accepted consideration. Furthermore, Indonesia must initiate cooperation with the sensing states to obtain the primary and processed data, to find out what kind of data captured by the satellites as long as it is in accordance with the sensing state's international obligations (for instance, to protect trade secrets).

Moreover, as the Remote Sensing Principles is the only international instrument governing remote sensing, it is reasonable enough for states to negotiate for a treaty or convention concerning the operation. Although some of the principles may be acknowledged as customary international law, it is undeniable that it is merely a resolution. The future treaty may contain the principles of shutter control so that in the event of an emergency or due to national security reasons, the sensed states could ask for the right of priority access, the right to interrupt the services, and the right to do a security check for the data before being distributed. 
Therefore, remote sensing operators are still being able to do their operations, and national security can also be protected.

\section{Conclusion}

Lieutenant General Bambang Darmono from the Indonesian National Armed Forces describes the concept of national security to include national defense, internal security, public security, and human security. ${ }^{88}$ Indonesia should have a specific regulation regarding licensing, data distribution/ dissemination, and security check to protect its national security thoroughly. As shutter control is now practiced by most states, the author believes that states that do not have a shutter control law may also exercise it through negotiation with operators. Nevertheless, the government should have a specific regulation concerning remote sensing to empower the government to exercise control over the activities, and initiate cooperation with the sensing states. All in all, technological advancement is not something we should be afraid of, as remote sensing provides so many benefits to all states. However, states should have protective measures as well to keep up with such advancement.

\section{REFERENCES}

\section{A. Books}

Cheng, Bin, 2004, Studies in International Space Law, Clarendon Press, Oxford.

Christol, Carl Q., 1991, Space Law: Past, Present, and Future, Kluwer Law and Taxation, Boston.

Csabafi, Imre A., 1971, The Concept of State Jurisdiction in International Space Law: A Study in the Progressive Development of Space Law in the United Nations, Martinus Nijhoff, The Hague.

Diederiks-Verschoor, I. H. Ph. And Kopal, V., 2008, An Introduction to Space Law, Kluwer Law International BV, The Netherlands.

Dunk, Frans von der, et al., 2015, Handbook of Space Law, Edward Elgar Publishing, Massachusetts.

Harris, Elisa D. (ed.), 2016, Governance of DualUse Technologies: Theory and Practice, American Academy of Arts \& Sciences, Cambridge.

Harris, Ray (ed.), 2002, Earth Observation Data Policy and Europe, Swets \& Zeitlinger B.V., Netherlands.

Ito, Atsuyo, 2011, Legal Aspects of Satellite Remote Sensing, Brill Nijhoff, Boston.
LAPAN, 2014, The Remote Sensing Monitoring Program of Indonesia's National Carbon Accounting System: Methodology and Products, Version 1, LAPAN-IAFCP, Jakarta. Lyall, Francis, et al., 2016, Space Law: A Treatise, Ashgate Publishing, Surrey.

Oduntan, Gbenga, 2012, Sovereignty and Jurisdiction in the Airspace and Outer Space: Legal Criteria for Spatial Delimitation, Routledge, New York.

Pelton, Joseph N., et al. (eds.), 2013, Handbook of Satellite Applications, Springer, New York.

Rao, R. V., et al., 2017, Recent Developments in Space Law, Springer Nature, Singapore.

Sumardi, Juajir, 1996, Hukum Ruang Angkasa (Suatu Pengantar), PT Pradnya Paramita, Jakarta.

\section{B. Journals and Articles}

Committee on Global Change Research, National Research Council, Global Environmental Change: Research Pathways for the Next Decade, National Academy Press Washington DC, 1999.

Darmono, Bambang, "Konsep dan Sistem Keamanan Nasional Indonesia”, Jurnal

\footnotetext{
88 Bambang Darmono, “Konsep dan Sistem Keamanan Nasional Indonesia”, Jurnal Ketahanan Nasional, Vol. 15, 2010, p. 4.
} 
Ketahanan Nasional, vol. 15, 2010.

De Beer, Aniel Caro, "The Refusal of Access to High Resolution Remote Sensing Data for Reasons of National Security: A (New) Rule of Customary International Law?", Thesis, University of Pretoria, 2015.

Gillon, Thomas, "Regulating Remote Sensing Space Systems in Canada - New Legislation for a New Era”, Journal of Space Law, vol. 34, 2008.

Harris, Ray, and Browning, Richard, "Data Policy Assessment for GMES: Final Reports", EVK2-CT-2002-80012-DPAG., University of London, 2004.

International Law Association, "Report on the Legal Aspects of the Privatization and Commercialization of Space Activities", Space Law Committee, Berlin Conference, 2004.

Menzel, W. Paul, "Remote Sensing Applications with Meteorological Satellites", NOAA Satellite and Information Service, University of Wisconsin, Madison, available at $<$ https:// cimss.ssec.wisc.edu/rss/benevento/source/ AppMetSat06.pdf $>$.

Prober, Raphael, "Shutter Control: Confronting Tomorrow's Technology with Yesterday's Regulations", Journal of Law and Politics, vol. 19, 2003.

Schmidt-Tedd, Bernhard, and Kroymann, Max, "Current Status and Recent Developments in German Remote Sensing Law", Journal of Space Law, vol. 34, 2008.

Sneiffer, Youssef, "The Implication of National Security Safeguards on the Commercialization of Remote Sensing Imagery", Seattle University Law Review, vol. 19, 1996.

Williams, S. M., "Reflections and Suggestions on Remote Sensing and International Law", German Journal of Air and Space Law, vol. 50, 2001.

Xie, Yichun, et al., "Remote Sensing Imagery in Vegetation Mapping: A Review", Journal of Plant Ecology, vol. 1, 2008.

\section{International Legal Instruments}

Convention on Civil Aviation, opened for signature 7 December 1944, 15 UNTS 295 (entered into force 4 April 1947).

Convention on International Liability for Damage Caused by Space Objects, opened for signature 29 November 1971, 961 UNTS 187 (entered into force 1 September 1972).

Principles Relating to Remote Sensing of the Earth from Outer Space, UN GA Res. 41/65, 3 December 1986, UN Doc. A/AC.105/572/ Rev.1.

Statute of the International Court of Justice, 18 April 1946, 33 UNTS 993.

Treaty on Principles Governing the Activities of States in the Exploration and Use of Outer Space, Including the Moon and Other Celestial Bodies, UN GA Res. 2222, 19 December 1966, UN Doc. A/RES/2222 (XXI).

\section{National Laws}

French Space Operations Act, 2008.

French Decree on Remote Sensing, 2009.

Indonesia Space Act, Law Number 21 Year 2013, SG.2013-133.

Kyl-Bingaman Amendment to the 1997 National Defense Authorization Act, 15 USC 5621.

Presidential Decision Directive 23, United States Policy on Foreign Access to Remote Sensing Capability, 1994.

Remote Sensing Data Policy, ISRO: EOS: POLICY-01: 2001.

Remote Sensing Space Systems Act, SC 2005.

Remote Sensing Space Systems Regulations, SOR/2007-66.

Satellite Data Security Act Federal Gazette BGBI.2007 I. No.58, 2007.

The Land Remote Sensing Commercialization Act, Public Law 98-365, 98th Congress, HR 5155, 1984. 
E. Cases

Continental Shelf (Libyan Arab Jamahiriya/Malta), Judgment, 1985 ICJ Reports 29.

North Sea Continental Shelf, Judgment, 1969 ICJ Reports 3.

Nuclear Weapons, Advisory Opinion, 1996 ICJ Reports 226.

Western Sahara, Advisory Opinion, 1975 ICJ Reports 12.

\section{F. Miscellanous}

CBC, "India wants Google Earth Maps Blurred", http://www.cbc.ca/news/technology/indiawants-google-earth-maps-blurred-1.638156, acessed 27 January 2017.

BBC News, "Google Earth Prompts Indian Fears", http://news.bbc.co.uk/go/pr/fr/-/l/hi/ technology/6331033.stm, acessed 27 January 2017.

GISGeography, "100 Earth Shattering Remote Sensing Applications and Uses", http:// gisgeography.com/100-earth-remotesensing-applications-uses/, acessed 27
January 2017.

Government Regulation Draft on Remote Sensing of the Republic of Indonesia, http://peraturan. go.id/penginderaan-jauh.html, acessed 27 January 2017.

National Aeronautics and Space Administration, "NASA, Japan Release Most Complete Topographic Map of Earth", https:// www.nasa.gov/topics/earth/features/ aster-20090629.html, acessed 27 January 2017.

Remote Sensing Technology and Data Center, http://pustekdata.lapan.go.id.

Rikin, Ari Supriyanti, "Lapan Serahkan Data Penginderaan Jauh Resolusi Tinggi pada 11 Instansi", http://www.beritasatu.com/ iptek/244745-lapan-serahkan-datapenginderaan-jauh-resolusi-tinggi-pada-11instansi.html, acessed 27 January 2017.

The Diplomat, "Indonesian Maritime Security Board to Access Chinese Satellite Data", https:// thediplomat.com/2014/10/indonesianmaritime-security-board-to-access-chinesesatellite-data/\#/disqus_thread, acessed 27 January 2017. 